\title{
Sizing and Economic Feasibility of Different Types of Solar Collectors for a Milk Producing Property in the Tropic
}

\author{
Eloiny G. Barbosa ${ }^{1}$, Marcos E. V. Araujo ${ }^{1}$, Elisa G. Barbosa ${ }^{2}$, Maria J. Moraes ${ }^{3}$, Javier H. F. Heredia ${ }^{1}$, \\ Felipe A. Gomes ${ }^{3} \&$ Rodrigo S. L. Araujo ${ }^{3}$ \\ ${ }^{1}$ Department of Agricultural Engineering, Federal University of Viçosa, Viçosa, Minas Gerais, Brazil \\ ${ }^{2}$ Department of Chemistry, State University of Goiás, Anápolis, Goiás, Brazil \\ ${ }^{3}$ Department of Agricultural Engineering, State University of Goiás, Anápolis, Goiás, Brazil \\ Correspondence: Marcos E. V. Araujo, Department of Agricultural Engineering, Federal University of Viçosa, \\ Viçosa, Minas Gerais, Brazil. Tel: 55-(62)-993-655-562. E-mail: marcos.rav@hotmail.com
}

Received: September 16, 2018

Accepted: October 25, 2018

Online Published: December 15, 2018

doi:10.5539/jas.v11n1p344

URL: https://doi.org/10.5539/jas.v11n1p344

The research is financed by National Council for Scientific and Technological Development (CNPq) and by Coordination for the Improvement of Higher Education Personnel (CAPES).

\begin{abstract}
To obtain quality milk, several hygiene measures must be taken during the milking process, especially cleaning the milking parlor and equipment using hot water. Thus, the objective of this study was to carry out the sizing and economic feasibility of two solar water-heating systems: flat plate solar collector (FPC) and evacuated tube solar collector (ETC) to clean milking parlors in the interior of Brazil. The sizing and economic feasibility of applicability of this study was carried out for a dairy farm located in the city of Anápolis-GO, Brazil. We calculate the energy produced by the solar collector, the necessary number of collectors, the net present value (NPV) and the time of return (RT) for all systems. The ETC presented higher energy produced per unit area (8590 to $12979 \mathrm{~kJ} \mathrm{~m}^{-2} \mathrm{day}^{-2}$ ) than the FPC $\left(6472\right.$ to $8699 \mathrm{~kJ} \mathrm{~m}^{-2}$ day-2). Furthermore, it presented a total required area around 33.5\% lower when compared to the FPC. The system that obtained the lowest total cost was the ETC with approximately US\$ 34441.00 . The two systems had positive NPV, and for ETC, this value was $7.2 \%$ higher. The return times for FPC and ETC were 3 years and 2 months and 2 years and 10 months, respectively. Both systems have proven their economic viability for heating water from milk producing properties, and may be an option for regions without energy access. In addition, the use of these systems contributes to the reduction of production costs and environmental impacts.
\end{abstract}

Keywords: cost reduction, milking parlor, solar energy, water heating

\section{Introduction}

The dairy industry contributes significantly to the Brazilian agribusiness (Canaza-Cayo et al., 2016). Brazil currently ranks as the sixth largest producer of bovine milk in the world, and in 2016 achieved production under government inspection of about 32.5 million metric tons (USDA, 2017). Although the country has specialized producers that invest in technology and obtains quality milk, a great part of the national production comes from small farmers (Lima et al., 2018). In Brazil, small farmers are generally characterized by low incomes and poor milk quality.

To obtain quality milk several hygiene measures must be taken during the milking process (Kull et al., 2017). Among these measures, we highlight the correct and daily cleaning of the milking parlor and milking equipment, which according to Willers et al. (2014) should be performed using hot water in order to ensure better hygiene. Due to the large volume of hot water used, this process is very intensive in energy, accounting for much of the cost of production. For Costa et al. (2018), infrastructure problems such as the lack of electrification and/or the high cost related to their use constitute the biggest barriers to obtaining quality milk. In Brazil, approximately 234 thousand families do not have access to electricity, many of them located in rural areas (IBGE, 2015), which exacerbates this situation. In this scenario, the search for alternative energy sources, which can help in solving these problems, becomes essential. 
Due to its wide availability and enormous generation potential, solar energy can be a viable alternative for obtaining thermal and electric energy in places that suffer from lack of access to conventional sources of energy and can contribute to a reduction of energy costs (Caliskan, 2017; Leonzio, 2017; Ossai, 2017). Brazil stands out as to the potential of solar energy production, as it is an extensive country and has much of its territory located near the Equator, receiving high solar radiation rates distributed throughout the year (Silva et al., 2016). Numerous research aimed at the use of solar energy for thermal applications has been carried out over the last few years (Basso et al., 2010; Siqueira et al., 2011; Lenz et al., 2017; Carli et al., 2018).

One of the main applications of solar energy is its use for heating fluids. Solar collectors are the main components of a solar heating system. These absorb radiation, convert it to heat and then transfer it to a working fluid, usually water (Ayompe et al., 2011; Zhou et al., 2017). Flat Plate Collectors (FPC) and Evacuated Tube Collectors (ETC) are the most widely used collectors for medium scale water heating applications (Shafieian et al., 2018). FPC are designed and widely used in various applications. Although FPC are durable, cheap and easily manufactured, they have high thermal loss values. ETC were introduced to address the challenges faced by the FPC. In this type of collector, the space between the two layers of glass tubes is evacuated and selective absorbers and transmitters are applied to reduce thermal losses. Although they are more efficient, their high cost and fragility are disadvantages when compared to the FPC (Rassamakin et al., 2013).

Studies on the sizing of solar water heating systems for milking applications are limited. Thus, the objective of this study was to carry out the sizing and economic feasibility of two solar water-heating systems: flat plate solar collector (FPC) and evacuated tube solar collector (ETC) to clean milking parlors in the interior of Brazil.

\section{Material and Methods}

\subsection{Characterization of the Milk Producing Property}

The sizing and economic feasibility of applicability of this study was carried out for a dairy farm located in the city of Anápolis-GO (16 $22^{\prime} 37^{\prime \prime} \mathrm{S}$ and $\left.48^{\circ} 48^{\prime} 08^{\prime \prime} \mathrm{W}\right)$, Brazil. The farm currently has 15 lactating Holstein cows, with an average daily production of 27 liters of milk per animal, totaling 405 liters. The water used for hygiene of the milking parlor comes from an artesian well. An electric resistance heats this water up to $70{ }^{\circ} \mathrm{C}$. The temperature of the water used for hygiene is in accordance with the Ministry of Agriculture, Livestock and Food Supply (MAPA) Regulation $\mathrm{n}^{\circ} 51$ of August 14, 2002.

\subsection{Sizing}

According to the Ministry of Agriculture, Livestock and Food Supply (MAPA) Normative $\mathrm{n}^{\circ} 51$ of August 14, 2002, for the hygiene of milking equipment, 100 liters of water per animal plus 6 liters of water per liter of milk produced must be used (Brasil, 2002). In this way, the producer has daily demand of 3930 liters of water at $70{ }^{\circ} \mathrm{C}$. Three options were evaluated for water heating with thermal reservoir: FPC, ETC and electric resistance heating (ERH). Due to unpredictability of climatic conditions, it was considered that an electrical resistance for $15 \mathrm{~h}$ monthly supplemented solar water heating systems.

The temperature of the supply water from the artesian well is approximately $20^{\circ} \mathrm{C}$. Thus, the energy required for the heating of water was calculated according to Equation 1.

$$
\mathrm{Q}_{\mathrm{N}}=\mathrm{m}_{\mathrm{w}} \cdot \mathrm{Cp}_{\mathrm{w}} \cdot\left(\mathrm{T}_{\mathrm{h}}-\mathrm{T}_{\mathrm{c}}\right)
$$

Where, $\mathrm{Q}_{\mathrm{N}}$ : energy required for heating water, $\mathrm{kJ} \mathrm{day}^{-1} ; \mathrm{m}_{\mathrm{w}}$ : amount of water demanded, $\mathrm{kg} ; \mathrm{Cp}_{\mathrm{w}}$ : specific heat of water, $4.184 \mathrm{~kJ} \mathrm{~kg}^{-1}{ }^{\circ} \mathrm{C}^{-1} ; \mathrm{T}_{\mathrm{h}}$ : hygiene water temperature ${ }^{\circ} \mathrm{C} ; \mathrm{T}_{\mathrm{c}}$ : supply water temperature ${ }^{\circ} \mathrm{C}$.

The electric energy consumption due to the heating of the water through the electric resistance was calculated according to Equation 2.

$$
\mathrm{C}_{\mathrm{e}}=\frac{\mathrm{Q}_{\mathrm{N}}}{3600} \cdot \mathrm{T}_{\mathrm{e}}
$$

Where, $\mathrm{C}_{\mathrm{e}}$ : electric energy consumption, $\mathrm{kWh}$ day $^{-1} ; \mathrm{T}_{\mathrm{e}}$ : electrical tariff, $\mathrm{US} \$ \mathrm{kWh}^{-1} ; 3600$ : Conversion factor from $\mathrm{kJ}$ to $\mathrm{kWh}$;

The thermal energy produced by each system was calculated according to Equation 3 (Kalogirou, 2014). The sizing was performed considering the worst situation, that is, the month of the lowest incident solar radiation, whose daily average is about $17080 \mathrm{~kJ} \mathrm{~m}^{-2}$.

$$
\mathrm{Q}_{\mathrm{P}}=\eta_{\mathrm{S}} \cdot \mathrm{A} \cdot \mathrm{I}
$$

Where, $\mathrm{Q}_{\mathrm{P}}$ : energy produced by collector, $\mathrm{kJ}^{\mathrm{day}}{ }^{-1} ; \eta_{\mathrm{S}}$ : thermal efficiency of each system; A: thermal absorption area of each collector, $\mathrm{m}^{2}$; I: daily total solar radiation, $\mathrm{kJ} \mathrm{m}^{-2}$ day ${ }^{-1}$. 
The average monthly data of solar radiation were obtained from the automatic surface observation meteorological station of the National Institute of Meteorology (INMET) (16 38 $38^{\prime} 34^{\prime \prime} \mathrm{S}$ and 49 $\left.13^{\prime} 13^{\prime \prime} \mathrm{W}\right)$.

The sizing of the number of required collectors $(\mathrm{Nc})$ was performed according to Equation 4.

$$
\mathrm{N}_{\mathrm{c}}=\frac{\mathrm{Q}_{\mathrm{N}}}{\mathrm{Q}_{\mathrm{P}}}
$$

The selected absorption areas were $2.00 \mathrm{~m}^{2}$ for the FPC and $4.64 \mathrm{~m}^{2}$ for the ETC. The average efficiencies of the systems (collector-thermal reservoir) used in this study were $37.9 \%$ and $50.3 \%$ for FPC and ETC respectively. Ayompe et al. (2011) obtained these values experimentally under similar solar conditions. The chosen thermal reservoir has a volume capacity of 4000 liters, serving the amount demanded daily. In addition, this thermal reservoir is equipped with electric resistance and adjustable thermostat.

\subsection{Economic Feasibility}

We analyzed the total cost of all systems, the net present value (NPV) based on the heating performed only by electrical resistance and the investment return time (RT). In the sizing, it was considered a planning horizon of 15 years for the useful life of the systems, US\$ 53.50 per year for the maintenance of these systems (referring to the cleaning of the components). Besides that, interest rate of $12 \%$ per year, cost of electric energy equal to 0.10861337 US\$ $\mathrm{kW}^{-1} \mathrm{~h}^{-1}$ (ENEL, 2018), inflation of 4.19\% per year and increase in electric energy above inflation of $1.5 \%$ per year. It was also considered that there was no subsidy in the purchase of the components of the systems (collectors and reservoir). Installation cost, including connections, was adopted, equal to $20 \%$ of the total value of each system (Altoé \& Oliveira Filho, 2010).

\section{Results and Discussion}

The average energy produced per square meter for each of the systems can be seen in Figure 1. As expected, the average energy per unit area produced by ETC was higher for all months of the year when compared to FPC. This result evidences the difference between the thermal efficiencies presented by each of the systems.

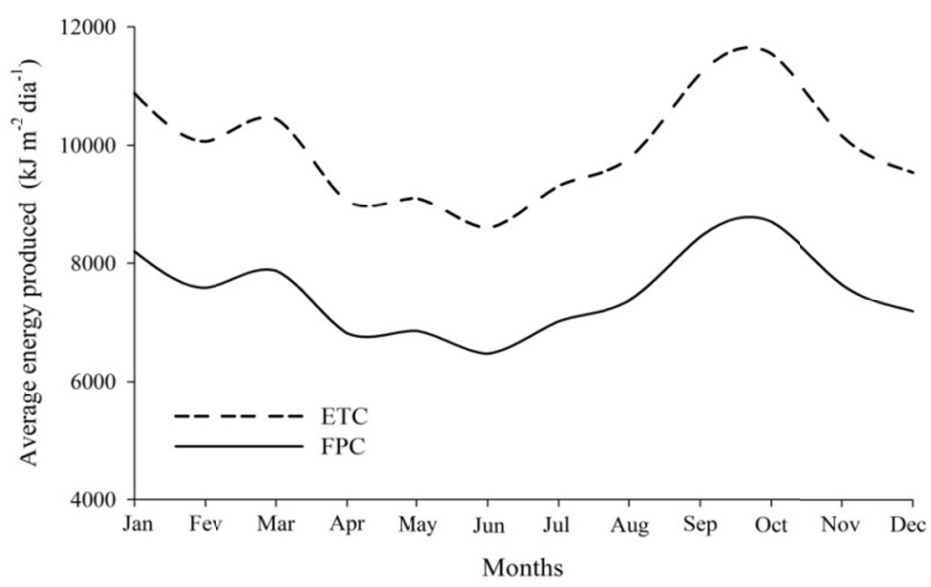

Figure 1. Average energy produced per unit area for the flat plate solar collector (FPC) and solar collector evacuated tube (ETC)

The ETC presented values of average energy produced between 8590 and $12979 \mathrm{~kJ} \mathrm{~m}^{-2}$ day $^{-2}$, while for FPC these values varied between 6472 and $8699 \mathrm{~kJ} \mathrm{~m}^{-2} \mathrm{day}^{-2}$. The values found in this study corroborate those found by Ayompe et al. (2011), which evaluated the average energy produced for ETC and FPC, found values ranging from 7560 to $11520 \mathrm{~kJ} \mathrm{~m}^{-2}$ day $^{-2}$ and 5040 to $8280 \mathrm{~kJ} \mathrm{~m}^{-2}$ day ${ }^{-2}$, respectively. The month of June presented the lowest average energy produced for the two systems. The winter solstice occurs in the southern hemisphere in the month of June, making this month the lowest incidence of solar radiation.

The Table 1 shows the total cost and NPV of the analyzed systems, considering a 15 -year useful life. It can be observed that to supply the same daily energy demand, the total area occupied by the FPC was $33.5 \%$ higher than that occupied by the ETC. It should be noted that the total area of the systems was obtained considering the month of least incident solar radiation, so there will be excess thermal energy produced for the other months of the year. In this way, surplus energy can be used for other applications in rural property, such as domestic use. 
Table 1. Total cost and net present value (NPV) in the useful life of the analyzed systems

\begin{tabular}{llll}
\hline \multirow{2}{*}{ Parameters } & \multicolumn{3}{c}{ Systems } \\
\cline { 2 - 4 } & ERH & FPC & ETC \\
\hline Number of collectors $\left(\mathrm{N}_{\mathrm{c}}\right)$ & - & 65 & 21 \\
Total occupied area $\left(\mathrm{m}^{2}\right)$ & - & 130.0 & 97.4 \\
Unit price (US\$) & - & 264.8 & 695.4 \\
Thermal reservoir (US\$) & - & 5005.8 & 5005.8 \\
Installation Cost (US\$) & - & 4443.2 & 3921.6 \\
Maintenance (US\$) & - & 802.3 & 802.3 \\
Cost with electricity (US\$) & 151217.1 & 10107.9 & 10107.9 \\
Total cost (US\$) & 151217.1 & 37571.2 & 34441.0 \\
NPV (US\$) & - & 38039.2 & 40785.3 \\
\hline
\end{tabular}

Note. ERH: Electric resistance heater; FPC: Flat plate solar collector; ETC: Evacuated tube solar collector.

The system that presented the lowest total cost in the useful life considered was ETC. The ERH does not present costs with the purchase of equipment, installation and maintenance, since this system is already installed in the property. Even so, this system presents the highest total cost over 15 years, in relation to the others, due to the high cost of electric energy. The use of FPC and ETC would generate savings of approximately $75.2 \%$ and $77.2 \%$, respectively, when compared to ERH. These economies are in agreement with those found by Altoé and Oliveira Filho (2010), evaluating solar heating systems with and without concentrator. The NPV values were positive for both systems, indicating that the investment would be economically feasible for both systems. However, the ETC showed a $7.2 \%$ higher NPV than the FPC, indicating that this system is more attractive financially.

The investment return times for the systems were 2 years and 10 months for ETC and 3 years and 2 months for FPC (Figure 2). After these periods, the cost of electricity to heat the water would be totally converted into profit for the producer. Nájera-Trejo et al. (2016) when evaluating the feasibility of the use of FPC and ETC for domestic water heating, found return times of 9 and 11 years, respectively. These values are higher than those found in this study, and are due to the low energy demand considered by the authors. At the end of the systems useful life, the producer would have a positive cash flow of approximately US\$ 113663.00 for the FPC and US\$ 116605.00 for the ETC. This demonstrates that the use of solar collectors for water heating for hygiene of milking parlors is a viable alternative to reduce energy expenditure. In addition, the use of solar energy promotes a reduction in environmental impacts and may be an affordable option for regions suffering from a lack of access to electricity.

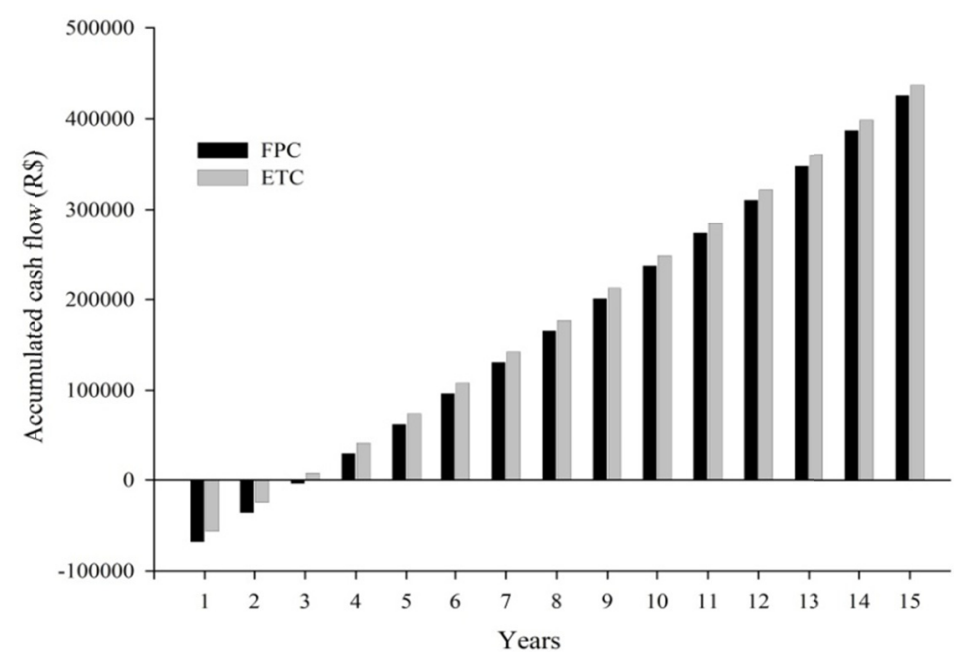

Figure 2. Cumulative cash flow for flat plate solar collector (FPC) and evacuated tube solar collector (ETC) over the lifetime 


\section{Conclusions}

The ETC presented higher energy produced per unit area (8590 to $12979 \mathrm{~kJ} \mathrm{~m}^{-2}$ day $^{-2}$ ) than the FPC (6472 to $8699 \mathrm{~kJ} \mathrm{~m}^{-2} \mathrm{day}^{-2}$ ). Furthermore, it presented a total required area around $33.5 \%$ lower when compared to the FPC. The system that obtained the lowest total cost was the ETC with approximately US\$ 34 441.00. The two systems had positive NPV, and for ETC, this value was $7.2 \%$ higher. The return times for FPC and ETC were 3 years and 2 months and 2 years and 10 months, respectively. Both systems have proven their economic viability for heating water from milk producing properties, and may be an option for regions without energy access. In addition, the use of these systems contributes to the reduction of production costs and environmental impacts.

\section{References}

Altoé, L., \& Oliveira Filho, D. (2010). Utilização de sistemas fototérmicos com concentradores para higienização de salas de ordenha. Engenharia Agrícola, 30, 799-810. https://doi.org/10.1590/S0100-6916 2010000500003

Ayompe, L. M., Duffy, A., McKeever, M., Conlon, M., \& McCormack, S. J. (2011). Comparative field performance study of flat plate and heat pipe evacuated tube collectors (ETCs) for domestic water heating systems in a temperate climate. Energy, 36, 3370-3378. https://doi.org/10.1016/j.energy.2011.03.034

Basso, H. L., Souza, S., de Siqueira, N. M., Jair, A. C., Nogueira, C. E. C., \& Santos, R. F. (2010). Analise de um sistema de aquecimento agua para residências rurais utilizando energia solar. Engenharia Agrícola, 30, 14-21. https://doi.org/10.1590/S0100-69162010000100002

Caliskan, H. (2017). Energy, exergy, environmental, enviroeconomic, exergoenvironmental (EXEN) and exergoenviroeconomic (EXENEC) analyses of solar collectors. Renewable and Sustainable Energy Reviews, 69, 488-492. https://doi.org/10.1016/j.rser.2016.11.203

Canaza-cayo, A. W., Cobuci, J. A., Lopes, P. S., Torres, R. A., Martins, M. F., Daltro, D. S., \& Silva, M. V. G. B. (2016). Genetic trend estimates for milk yield production and fertility traits of the Girolando cattle in Brazil. Livestock Science, 190, 113-122. https://doi.org/10.1016/j.livsci.2016.06.009

Carli, R. L., Santos, R. F., Siqueira, J. A. C., Nogueira, C. E. C., Zago, E. A., \& Tokura, L. K. (2018). Economic viability of photovoltaic systems in a rural community in Brazil. Journal of Agricultural Science, 10, 303-316. https://doi.org/10.5539/jas.v10n7p303

Costa, H. B. A., Dantas, R. M., Alvarenga, M. B., Peripolli, V., Tanure, C. B., \& McManus, C. (2018). Programs for best dairy management practice in Brazil and their applications. Journal of Cleaner Production, 176, 1026-1033. https://doi.org/10.1016/j.jclepro.2017.11.240

ENEL (Ente Nazionale per L'energia Elettrica). (2018). Tarifas, Taxas e Impostos. Retrieved from https://www.eneldistribuicao.com.br/ce/TaxasETarifas.aspx

IBGE (Instituto Brasileiro de Geografia e Estatística). (2015). Domicílios particulares permanentes e Moradores em domicílios particulares, por classes de rendimento mensal, situação do domicílio e iluminação elétrica. Retrieved from https://sidra.ibge.gov.br/tabela/1959

Kalogirou, S. A. (2014). Solar Energy Engineering_Processes and Systems (2nd ed.). Boston, USA.

Kull, J. A., Ingle, H. D., Black, R. A., Eberhart, N. L., \& Krawczel, P. D. (2017). Effects of bedding with recycled sand on lying behaviors, udder hygiene, and preference of lactating holstein dairy cows. Journal of Dairy Science, 100, 7379-7389. https://doi.org/10.3168/jds.2016-12307

Lenz, A. M., Colle, G., Souza, S. N. M., Prior, M., Nogueira, C. E. C., Santos, R. F., Friedrish, L., \& Secco, D. (2017). Evaluation of three systems of solar thermal panel using low cost material, tested in Brazil. Journal of Cleaner Production, 167, 201-207. https://doi.org/10.1016/j.jclepro.2017.08.149

Leonzio, G. (2017). Solar systems integrated with absorption heat pumps and thermal energy storages: state of art. Renewable and Sustainable Energy Reviews, 70, 492-505. https://doi.org/10.1016/j.rser.2016.11.117

Lima, L. P., Ribeiro, G. B. D., \& Perez, R. (2018). The energy mix and energy efficiency analysis for Brazilian dairy industry. Journal of Cleaner Production, 181, 209-216. https://doi.org/10.1016/j.jclepro.2018.01.221

MAPA (Ministério da Agricultura, Pecuária e Abastecimento). (2002). Instrução Normativa no 51, de 20 de setembro de 2002. Retrieved from https://wp.ufpel.edu.br/inspleite/files/2016/03/Instru\%C3\%A7\%C3\%A3 o-normativa-n\%C2\%B0-51-de-18-de-setembro-de-2002.pdf 
Nájera-Trejo, M., Martin-Domínguez, I. R., \& Escobedo-Bretado, J. A. (2016). Economic Feasibility of Flat Plate vs Evacuated Tube Solar Collectors in a Combisystem. Energy Procedia, 91, 477-485. https://doi.org/ 10.1016/j.egypro.2016.06.181

Ossai, C. I. (2017). Optimal renewable energy generation-Approaches for managing ageing assets mechanisms. Renewable and Sustainable Energy Reviews, 72, 269-280. https://doi.org/10.1016/j.rser.2017.01.041

Rassamakin, B., Khairnasov, S., Zaripov, V., Rassamakin, A., Alforova, O. (2013). Aluminum heat pipes applied in solar collectors. Solar Energy, 94, 145-154. https://doi.org/10.1016/j.solener.2013.04.031

Shafieian, A., Khiadani, M., \& Nosrati, A. (2018). A review of latest developments, progress, and applications of heat pipe solar collectors. Renewable and Sustainable Energy Reviews, 95, 273-304. https://doi.org/10.1016 /j.rser.2018.07.014

Silva, R. C., Marchi Neto, I., \& Seifert, S. S. (2016). Electricity supply security and the future role of renewable energy sources in Brazil. Renewable and Sustainable Energy Reviews, 59, 328-341. https://doi.org/10.1016/ j.rser.2016.01.001

Siqueira, D. A., Vieira, L. G. M., \& Damasceno, J. J. R. (2011). Analysis and performance of a low-cost solar heater. Renewable Energy, 36, 2538-2546. https://doi.org/10.1016/j.renene.2011.02.019

USDA (United States Department of Agriculture). (2017). Brazil: Dairy and Products Annual, Annual Dairy Report (GAIN Repport Number: BR1719). Retrieved from https://gain.fas.usda.gov/Recent\%20GAIN\% 20Publications/Dairy\%20and\%20Products\%20Annual_Brasilia_Brazil_10-26-2017.pdf

Willers, C. D., Ferraz, S. P., Carvalho, L. S., \& Rodrigues, L. B. (2014). Determination of indirect water consumption and suggestions for cleaner production initiatives for the milk-producing sector in a Brazilian middle-sized dairy farming. Journal of Cleaner Production, 72, 146-152. https://doi.org/10.1016/j.jclepro. 2014.02.055

Zhou, F., Ji, J., Cai, J., \& Yu, B. (2017). Experimental and numerical study of the freezing process of flat-plate solar collector. Applied Thermal Engineering, 118, 773-784. https://doi.org/10.1016/j.applthermaleng. 2017.02.111

\section{Copyrights}

Copyright for this article is retained by the author(s), with first publication rights granted to the journal.

This is an open-access article distributed under the terms and conditions of the Creative Commons Attribution license (http://creativecommons.org/licenses/by/4.0/). 